\title{
GROWING THE MALAYSIAN VENTURE CAPITAL AND PRIVATE EQUITY INDUSTRY
}

\author{
Syed Adil Hussain*
}

\begin{abstract}
The venture capital (VC) and private equity (PE) industry in Malaysia is at a crossroads. Despite having received RM3 billion in government aid, according to practitioners the industry will be devoid of any privately-backed organisations within five years if further action is not taken. This situation is problematic for many reasons - not least being that the government believes a robust venture capital and private equity sector would contribute to Malaysia's development goals. Through a review of existing academic literature and in-depth interviews with 25 senior executives of Malaysian financial firms, this article investigates the state of the Malaysian VC/PE industry, and whether the government should intervene to improve its condition. Many financial executives argue that government intervention to aid the VC/PE sector is necessary at the present juncture. Although government efforts to grow VC/PE sectors have yielded less than desirable results in many nations, scholars have noted that a well-structured intervention can minimise such risks. In order to overcome those problems, this article recommends the creation of a RM1 billion 'fund-of-funds'.
\end{abstract}

\section{Introduction}

Malaysia's current five-year plan calls for the full-scale industrialisation of its economy by 2020 , a process that will require the country "to continue ascending the technological ladder to high-tech types of industrial production, with a corresponding increase in the intensity of capital investment". ${ }^{1}$ The development of a robust venture capital (VC) and private equity (PE) industry is identified as a key component in this ambitious plan, as the government has concluded that a strong VC/PE sector would propel Malaysia towards its development goals. What is the state, therefore, of the Malaysian $\mathrm{VC} / \mathrm{PE}$ industry, and can and should the government intervene to improve its condition?

More specifically, this article will attempt to answer the following questions (whereby the answer to the first question is informed principally by a review of

* Syed Adil Hussain is the founder of the online education company uProdigy and currently a graduate student at Harvard University. In 2009, he was a Visiting Research Fellow at IAIS Malaysia.

ICR 1.4 Produced and distributed by Pluto Journals ICR.plutojournals.org 
existing academic literature, and the second and third by a series of 25 interviews with senior executives of Malaysian financial firms):

1. If a robust venture capital/private equity industry does not develop through market processes, can and should the government intervene?

2. Past government initiatives to construct a venture capital/private equity industry have not yet achieved their objectives. Is future action by the Malaysian government warranted?

3. If further intervention is warranted, how should it be structured?

According to its proponents, the benefits of early-stage private equity, or venture capital, as a driver of economic growth are well-established. Venture capital groups bridge the funding gap, help build an ecosystem of entrepreneurs and thus encourage innovation, and provide a mechanism through which seasoned management can work with newer management teams and companies to improve their corporate governance and execution strategies. In the United States in particular, the venture capital industry is alleged to have underpinned the emergence and growth of Silicon Valley as one of the world's leading centres of innovation over the last 40 years, with the funding of companies such as IBM, Google, Apple and HP. ${ }^{2}$

Researchers' understanding of the utility and performance of the venture capital and private equity industry, however, remains at a relatively early stage. Measuring the investment returns of the industry is notoriously challenging due to the lack of transparency in reporting. ${ }^{3}$ Poorly performing funds have a strong disincentive to have their results widely known and thus there tends to be a bias in available data towards funds with satisfactory performance. Complicating matters further, return rates can be definitively computed only after all investments have been exited or discharged, which typically takes about ten years. In the interim, the value of investee companies are measured and reported by the fund managers, who are incentivised to inflate the valuations. ${ }^{4}$ Many studies, moreover, suffer from a presence of bias in interpreting data.

Reliable scholars, such as Lerner, Schoar and Wong, ${ }^{5}$ have concluded that private equity returns are equal to or higher than those from public indices such as the S\&P 500. These findings have been substantiated by polls of investors who have allocated funds to PE; the 2008 Global PE Barometer by Coller Capital reported that 80 per cent of investors "planned to maintain or increase their target allocation over the next 12 months [...] in general, [investors] remained strongly committed to the asset class". 6

Early-stage private equity, or venture capital, provides greater support to the entrepreneurial ecosystem but on average yields lower investment returns than late-stage private equity due to the intrinsically risky nature of investing in start-up 
companies. ${ }^{7}$ Phalippou ${ }^{8}$ and Kedrosky ${ }^{9}$ argue that previous periods of high VC returns have caused the entrance of an overabundance of venture capital firms in the US, depressing average returns. Both authors argue that the US VC industry should shrink because of the saturation of the market, but acknowledge the importance of venture capital as a funding and mentoring source for new firms:

No one is seriously arguing that the venture capital industry will cease being crucial in driving the growth of important companies ... [in addition, this paper] should not take away from venture capital's role in financing growth companies. External capital is sometimes required by some private companies in their early stages, and it is good that there is a class of professional investors with enough financial resources to provide that assistance when it is needed. ${ }^{10}$

Most researchers have coalesced around the following points in regards to the utility of venture capital and private equity.

\section{Innovation and Economic Growth}

A large body of research by economists conclusively establishes the link between innovation and economic growth, which venture capital and private equity both catalyse. ${ }^{11}$ Venture capitalists invest in early-stage companies that may be considered too risky for other funding sources. Oftentimes these new start-up companies are founded on a new technology or innovation that would not be commercialised without the help of the venture capitalist. In a recent survey, 91 per cent of venturefunded firms said that the VC funding was responsible for their existence and survival, and also allowed them to grow more rapidly. ${ }^{12}$ In the United States, every dollar of venture capital funding appears to stimulate three to four times as many patents as a dollar of traditional corporate research \& development funding. ${ }^{13}$ Regarding private equity, investments are made in mature companies, and thus the sustainment of innovation is less marked. Nevertheless, several large-sample studies indicate that private equity also accelerates the pace of patent registration, acquisitions and divestitures. ${ }^{14}$

\section{Superior Operations/Management}

A key characteristic of $\mathrm{VC} / \mathrm{PE}$ investments is that the economic interests of the owners (i.e. the shareholders) and managers of investee companies are closely aligned; success depends on the VC/PE organisation's ability to improve the operations of the investee firm. After making investments $\mathrm{VC} / \mathrm{PE}$ organisations appoint top-quality talent to the management teams of the investee firms through their network of contacts; indeed, tapping VC organisations for their operational 
expertise and contacts is one of the primary reasons why many start-ups seek venture funding in the first place. In a study of over 4,000 firms in the United States, Europe and Asia, Bloom et al. ${ }^{15}$ showed that private equity-owned firms are on average the best managed. Firms purchased by private equity investors increase their productivity by about two percentage points more than those not owned by PE investors; this increased productivity is in turn reflected in the higher wages of employees at firms. ${ }^{16}$

Effect on industries. A World Economic Forum study which examined the impact of private equity investments across 20 industries in 26 major OECD nations between 1991 and 2007 found that industries where private equity funds have been active in the past five years grow more rapidly than other sectors, whether measured using total production, value added or employment. The study accounted for reverse causality. ${ }^{17}$

Cyclicality. There is an aspect of venture capital and private equity that can be detrimental - both are very cyclical. In the United States, there was a wave of increased VC/PE activity in the 1980s with leveraged takeovers, another toward the end of the 1990s with the internet bubble, and finally one in the years leading up to the subprime crisis. This cyclicality is a concern particularly when investors are foreign, as they are most likely to withdraw their capital from the country whenever there is doubt regarding the stability of the economy. In such a situation there would be less capital available to firms but the greater concern would be for private equity-acquired firms, which in some cases might be highly leveraged and fragile to busts in the economy. While there have been a few such cases that have caught the attention of the media, a rigorous analysis of this phenomenon is yet to be published. In addition, the effect would be mitigated by government involvement.

\section{Can and Should the Government Intervene to Create a Robust VC/PE Industry?}

Even if the merits of a robust venture capital and private equity industry are wellestablished, it does not necessarily follow that the government can or should intervene to prop up the industry. Government intervention is warranted when the benefits of a successful programme outweigh the costs of intervention more than with other possible uses of public resources.

\section{Case for Government Intervention}

Though there have been many failures, known successes have resulted partly from government intervention. Despite popular perceptions, every major locus of entrepreneurial activity in the world has benefited from some government aide at the 
outset. ${ }^{18}$ The activities of the Small Business Investment Corporation (SBIC) in the 1960s and 1970s led to the development of much of the venture capital industry in Silicon Valley. "Many of the early VC funds and leading intermediaries in the industry - such as law firms and data providers - began as organizations oriented to the SBIC funds and then gradually shifted their focus to independent VCs. Similarly, public programs played an important role in triggering the explosive growth of virtually every other major venture market around the globe."19

Getting the ball rolling - every improvement makes the next easier. As a technology hub develops, it becomes increasingly easy for firms to find talent and VCs to find deals but pioneers usually face difficulty and deliver poor results. This pattern is certainly evident in the United States venture industry, which delivered low returns in its early days. It is during these early days when government aid is most justified. ${ }^{20}$

Certification. The government can identify new teams that would not be able to commence their activities otherwise. Indeed, researchers for the World Economic Forum recently analysed 28,800 firms around the globe and found that those with modest levels of venture funding from government-backed sources outperformed even those firms with only private venture capital backing. ${ }^{21}$

Success in Malaysia could be transformative - enormous upside outweighs the risks. Developing a robust venture capital and private equity industry could play a transformative role in Malaysia's economy. Even in its limited stage of development, Deputy Finance Minister Datuk Awang Adek Hussin noted that "venture capital and private equity have made a profound impact on the Malaysian economy, filling the gap between direct bank lending and financing through debt or equity markets". ${ }^{22}$

\section{Case Against Government Intervention}

In weighing a government initiative, consideration must be given to the possibility that the initiative will not yield its intended consequences:

Incompetence. Government officials can be incompetent or suffer from information asymmetries as a result of not being 'in the field'; policies that may seem reasonable in the halls of capitals sometimes make little sense to those in the private sector. Lerner describes, for example, a French effort to develop a Silicon Valley-like entrepreneurial cluster in Brittany. Brittany, however, has little tradition for entrepreneurship or high-technology industry; the development of such entrepreneurial clusters depends critically on a confluence of historical and cultural factors. ${ }^{23}$ The initiative in Brittany suffered from another type of problem as well - it was pared down as other French provinces demanded a share of the investment programme. 
Malaysia, for its part, enjoys strong links between industry and policymakers which should in principle reduce government missteps resulting from a lack of information, but many government initiatives have nevertheless suffered from a lack of proper planning and political jockeying. If, as Nobel Prize laureate Douglass North argued, governments become more competent as GDP per capita increases, the failure of government intervention for venture capital in nations such as France should lead to a cautious stance in Malaysia. ${ }^{24}$

Sectarian politics. Several academics have argued that ethnic homogeneity leads to better governments, as "in diverse societies, political winners all too often have focused their energies on expropriating wealth (or worse) from other ethnic groups and enact measures that reinforce their hold on power". ${ }^{25}$ Indeed, in several interviews Malay financial executives spoke about the need of government initiatives to increase entrepreneurship amongst Malays, oftentimes at the expense of the Chinese. An example of such a policy was the 'payong scheme', which was conceived as a way for Malays to penetrate the furniture market which was then dominated by the Chinese. Ten Malay entrepreneurs received significant support from the government to export furniture, and their dependence on the government was gradually decreased after a number of years. Such initiatives do little to improve the global competitiveness or aggregate level of wealth of Malaysia, while wasting valuable public resources that could be put to more productive use. Indeed, a doctorial dissertation by Syahira Hamidon for Massey University of New Zealand in 2009 argued that affirmative action policies in Malaysia resulted in deleterious consequences:

Government privileges and assistance to Malays to promote entrepreneurship do not help much in boosting an entrepreneurial culture nor do they help in enhancing entrepreneurial competitiveness and achievement. Instead, such privileges and assistance have conversely made the Chinese more resilient and competitive entrepreneurially but discriminative against the Malays. ${ }^{26}$

Public efforts to increase Malay ownership at the expense of the Chinese are likely to be counterproductive in building a viable Malaysian entrepreneurial class and venture capital industry; policymakers should be aware that intervention to support $\mathrm{VC} / \mathrm{PE}$ in Malaysia may fall victim to this danger.

Regulatory capture. An extensive body of academic literature documents the phenomenon of regulatory capture, wherein government, industry or other agents organise to win the subsidies and monies distributed through government initiatives. Lerner cites two large-sample studies of Israel and Spain which show that most subsidies are won by large firms, as they are able to devote manpower to focus on receiving government contracts and subsidies. In the United States, many firms even 
set up offices in Washington DC for this purpose. And in contrast to small firms, large firms decrease their own funding for independent research and development after receiving grants. Many of the potential perils associated with government intervention, can, however, be mitigated with proper planning in a manner that judiciously analyses the successes and failures of similar initiatives around the globe. Policymakers will in the end have to judge for themselves whether the potential benefits for Malaysia outweigh the risks.

\section{Is Future Action by the Malaysian Government Warranted?}

Although public intervention is warranted in some cases, past efforts to build a viable $\mathrm{VC} / \mathrm{PE}$ sector in Malaysia have not yet been successful. This section reviews some of the government programmes and analyses whether further action is warranted. Data were gathered through interviews with 25 senior executives of financial firms in Malaysia.

\section{Previous Government Efforts to Grow a Malaysian VC/PE Industry}

Indirect efforts. In the 1970s, Malaysian government leaders began to focus on entrepreneurship as a means to economic growth. The next two decades saw the broadening of the economy from being primarily a producer of commodities to one driven by exports, primarily of electronics. The government played a major role in this transition through the promotion of a free trade regime, a skilled fiscal and monetary policy, and a series of innovative programmes that attracted massive foreign investment. ${ }^{27}$ Many public sector initiatives, in addition, aided the VC/ PE industry indirectly, through efforts to create a more hospital environment for entrepreneurship. "Initiatives in the 1970s were exhaustive. Overall they worked in creating an awareness, inclination, and competency for entrepreneurship. By 1980, there was a middle class based on entrepreneurship," noted Dato' Adnan Alias, CEO of the Islamic Banking and Finance Institute Malaysia. Industry leaders understood, however, that Malaysia could not rely on its cost advantage in exports forever, as manufacturing would eventually migrate to countries with lower cost structures. By the early 1990s Malaysia's leaders understood that promoting innovation and venture capital was central to securing further economic growth. ${ }^{28}$

In 1992, the government set up the Malaysian Technology Development Corporation (MTDC), to provide technical advice and assistance to entrepreneurs. Six years later it created five university-linked incubators to facilitate the commercialisation of ideas from university labs. ${ }^{29} 1993$ saw the establishment of the Malaysian Industry-Government Group for High Technology (MIGHT) which focused on creating linkages between public and private sector technology industries. MIGHT, in turn, advocated for initiatives like the Multimedia Super 
Corridor (MSC).$^{30}$ The MSC, a special economic zone modelled after Silicon Valley, was part of a significant push in 1995 by Prime Minister Mahathir Mohamad for innovation and entrepreneurship. "It was a very exciting and visionary initiative for an Asian country, and firms around the world were very impressed," noted David Fong, Chairman of the Malaysian Venture Capital and Private Equity Association. Also in 1995, the Malaysian government set up the Ministry of Entrepreneur Development (KPUn) to instil entrepreneurship values in the public. The total number of participants in 2001-06 according to one source was $164,786 .{ }^{31}$

A systematic analysis of these programmes is beyond the scope of this article, but it is safe to say that a great many have suffered from design flaws that reduced their efficacy. BioValley, for example, was built on the site of Entertainment Village, a previous and failed government initiative to create a major domestic film industry. Repeating their mistake, policymakers did not adequately think through the value proposition that the region offered to prospective tenants of BioValley, who were concerned that Malaysia did not have a sufficient number of experts to sustain a cutting edge facility. Moreover, shortly after the commencement of the programme the government announced the creation of similar facilities in all of Malaysia's provinces with each focusing on its own specialty. This announcement led many to question the government's commitment to BioValley. "A2 "A short-term view has impeded many development efforts in Malaysia," noted one executive. The outcome of BioValley and other government-led programmes offers a lesson to policymakers - public policy initiatives to build entrepreneurship and venture capital often follow 'hot' industries based on 'buzz'. Forty nine of 50 US states, for example, have devoted public funds to start biotechnology industries in their states, but few have a chance of being successful. ${ }^{33}$

Direct efforts. The Asian financial crisis struck in 1997, sending the Malaysian GDP per capita plummeting from US\$4,530 in 1997 to US\$3,390 in 1999, a decline of 25 per cent. Taiwan, in contrast, was less affected, with a contraction in GDP per capita of 2 per cent. ${ }^{34}$ "Taiwan was relatively less affected according to Malaysian policymakers because from the outset it was the most similarly modelled after Silicon Valley, including venture capital and entrepreneurship. It also benefited from the Taiwanese returnees from the United States, particularly the West Coast," recalled David Fong. This view led to the greater emphasis on the generation of a viable venture capital/private equity industry as a national priority.

In 2001 the Malaysian government established its own venture capital firms, including Malaysia VC Management (MAVCAP) and Kumpulan Modal Perdana (KMP); these two organisations in addition to the MTDC were given 1 billion ringgit to invest. ${ }^{35}$ MAVCAP had an additional mandate to create independent venture capital firms by distributing seed money of 25 to 30 million ringgit to 
aspiring venture capital teams. These initial funds were then to be invested in young technology companies, which would hopefully offer good returns to the young VC firms. Through this positive track record, the $\mathrm{VC}$ funds would then be able to raise additional money from investors and subsequently help create the next generation of Malaysian technology firms. The design of the plan reflected good planning and understanding of the venture market, but there were numerous problems. First, the initiative started at the worst possible time: 2001. Venture capital firms around the world suffered huge losses during the collapse of the internet bubble. Second, MAVCAP's mandate was to invest in information and communications technology. The new venture capitalists were thus asked to invest at the worst time in the worst sector. Third, MAVCAP itself was forced to maintain certain investment levels in start-up companies despite the attractiveness of the opportunities. As a result, ten years later, despite instances of successful investments, MAVCAP and its venture capital start-ups have yet to meet their performance objectives.

Despite these setbacks, the Malaysian government has continued to be remarkably proactive. "The industry is basically not taxed," noted Jennifer Chang, Partner at PricewaterhouseCoopers. In January 2005, the Malaysian government established the Malaysian VC Development Council (MVCDC), which acts as a platform for policymakers and industry players to discuss matters relating to the development of industry and to channel views and strategies to government. The government has in addition offered grants under various ministries and allocated RM1.6 billion for venture capital under the 9th Malaysian plan (2006-10), twice the amount allocated to $\mathrm{VC}$ under the previous plan, and liberalised equity ownership for venture capital firms.

More recently, the government has set up two private equity funds of interest. The first, Ekuinas, is a RM10 billion strategic development company designed to burnish Malay ownership of business. This goal is to be achieved by the purchase of stakes in private non-Malay owned businesses. A notable feature of the fund is that it will outsource RM300 million of investments to private equity firms. This feature will reduce or eliminate the "crowding out" effect of this policy that would otherwise stress the $\mathrm{VC} / \mathrm{PE}$ industry - since most government-linked funds in Malaysia invest in deals directly, they create additional competition for domestic $\mathrm{VC} / \mathrm{PE}$ firms. "There is a constant flow of people to the Gulf from Malaysia to promote standard projects for direct funding, but this is not for funds. Singapore raises capital the right way - they don't have specific projects in Singapore, so they go to promote their funds," noted Chok Kwee Bee, Managing Director of Walden International. Indeed, according to The Economist, "the Canadian government's experiment with venture capital failed because the Canadian Labor Fund Program had so much money that it frightened off private venture capitalists, while earning 
mediocre returns itself. New Zealand's government, in contrast, did much better because it invested public money in private funds. ${ }^{" 36}$

The second fund, 1Malaysia Development fund, promotes foreign investment into Malaysia; the organisation in the fall of 2009 signed a deal wherein it will contribute US $\$ 1$ billion to a US $\$ 2.5$ billion fund jointly managed with PetroSaudi International Limited. ${ }^{37}$ In January 2010 1Malaysia signed a deal with Chinese utility giant State Grid Corp of China (SGCC) to undertake up to US\$8 billion in investments in Sarawak, including one aluminium plant and three hydro-electric dams. According to Malaysian Prime Minister Najib, "the entry of SGCC, which reported over US $\$ 160$ billion revenue and US\$273 billion assets last year, and its significant investment in Score will pave the way for more substantial investments from China and globally into Malaysia".

\section{Current State of the Industry}

While the impact of Ekuinas and the various aforementioned government initiatives remains to be seen, the Malaysian VC/PE industry thus far remains undeveloped. "While significant efforts have been made and progress achieved over the past ten years, the VC industry continues to face many challenges. It is at a crossroads and in serious need of a review or revamp if it is to play its intended role in the coming years," said David Fong, Chairman of the Malaysian Venture Capital and Private Equity Association. Many executives spoke of the profound difficulty in raising funds as a prime reason for this lack of industry progression. "Investors lack an understanding of the risk/reward profile involved, which is a function of the evolution of the Malaysian financial industry. They tend to be steeped in training of banking and credit, but don't understand entrepreneurship," said one executive. "Insurance companies are too cautious... they are happy with 4-5 per cent returns that are guaranteed by the government," noted Lim Yong Lee of AMInvestment Bank.

\section{Limited Allocation by Domestic Institutional Investors}

It is indeed true that global institutional investors are much more open to investing in private equity. Pension funds according to Preqin on average allocate " $4.8 \%$ of their assets under management ( $\mathrm{AuM}$ ) to private equity... the 20 largest pension funds in the world have committed $\$ 208$ billion to PE, representing $8.6 \%$ of their combined AuM [...] highlighting the importance of private equity as a diversification tool for their portfolios". ${ }^{38}$ These relatively high allocation rates are driven by "superior rates of return relative to other asset classes - in one of the worst years on record, 2008, 78\% of investors said their investments in PE met or exceeded their expectations, with only $22 \%$ saying their returns were worse than expected". 
In other emerging markets around the globe, "managers are well capitalised and positioned to capture attractive investment opportunities. In 2008, emerging market funds raised $\$ 64 \mathrm{bn}$ in fresh capital, or ten times the amount raised in 2004 and, despite the difficult fundraising environment, almost 9\% more than in 2007. ${ }^{139}$ In the Malaysian context, few institutional investors aside from the Employee's Provident Fund and the AIA have made allocations to private equity; total investments from pensions and public funds in the industry were RM62,040,000 (1.38 per cent of total VC/PE funding) in 2007 and RM109,223,000 (2.39 per cent) in 2008. ${ }^{40}$ These institutional investors argue that many Malaysian VC/PE organisations simply do not have good track records. This is a sensible approach, but should be understood in the light of two points. First, the track records of Malaysian firms should be evaluated relative to those of other $\mathrm{VC} / \mathrm{PE}$ firms worldwide for the same time periods. Malaysian venture capital groups were not unique in making investments in failed information technology companies during the internet bubble years of the late 1990s. Second, nascent venture capital industries do not perform well at the outset, including in the case of pioneering firms in the United States.

Nevertheless, Malaysian institutional investors are not necessarily erroneous in taking a cautious approach to VC/PE. Many robust VC/PE industries have been driven by investment from global institutional investors, who have been investing in the industry for decades and are comfortable with the asset class. Domestic institutional investors have oftentimes assumed investment roles only after the market has been validated by global players. ${ }^{41}$

\section{Lack of Privately-Funded VC/PEs}

As a result of the difficulty in raising funds, there is what many interviewees describe as a dearth of independent $\mathrm{VC} / \mathrm{PE}$ organisations. This situation is problematic because VC/PE organisations backed by banks or the government are deemed to have organisational hierarchies or other characteristics that lead to poor returns: the risk appetite for government-backed VC/PEs as they are currently structured is low as the government debt must be serviced. And board members of banks, who usually have ultimate decision-making authority, tend to be risk-averse and to demand stable profitability year after year.

Proper VC/PE management requires taking risks and understanding that $\mathrm{VC} / \mathrm{PE}$ portfolios take time to mature. "The failure of BIMB Musharaka and the success of CIMB PE was determined by leadership that had very different understandings of how to manage their venture arms," said Encik Nor Idzam Yaakub, Founder of Musharaka Capital. "CIMB Private Equity is successful because we recognise different behaviour is required of different businesses - we allow our PE group to be very flexible. But most other bank-backed groups are restricted. I used to 
be at Bank Islam Berhard - they can't do anything without board approval," said Badlisyah Abdul Ghani, CEO of CIMB Islamic.

Incentives, in addition, are not aligned properly for government-backed VC/ PE funds; employees at such firms are paid like other government employees they don't earn "carry", meaning they do not significantly benefit from successful investments - and they are chided for bad investment decisions. Such incentives lead to an overly cautious investment approach, which, as noted by the CEO of CIMB Islamic, is not likely to be successful in the domain of VC/PE. Furthermore, there is no incentive for managers to stick with government-backed entities over the long-run. "If the investment manager has no vested interest in the ultimate success of the fund - there is no 'pain' for failure - it is a bad recipe," said David Fong.

A further consequence of the dearth of private $\mathrm{VC} / \mathrm{PE}$ organisations due to a difficulty in raising funds is that it is difficult for professionals to establish new funds. "Malaysian institutional investors will never invest in PE run by groups not backed by banks or big institutions. If they have the right track record working for a major firm, there is a need to nurture these individuals. Developing a sizeable class of venture capitalists will help Malaysia meet its development goals," said Lim Yong Lee of AMInvestment Bank.

\section{Deal Flow}

The sufficiency of adequate deal flow - the amount of good investment opportunities - was a major topic of discussion in interviews. Two interviewees argued that the $\mathrm{VC} / \mathrm{PE}$ industry is not performing well simply because there are not sufficient deals in Malaysia, and that growth of the VC/PE industry should be organic. That is, as the number of good investment opportunities increases, so too will the number of VC/PE organisations. "Why create investment funds when there are no good deals? Why not focus on creating good companies?" asked Lee Poh Cheong, Investment Director of AIA.

Others countered that if the government judged VC/PE important to the development of the economy, then government action was necessary at this juncture; "there are many instances when a government-pushed industry has become successful," said Dato' Adnan. "Government has to get the wheels turning," agreed Rashid Hussain, founder of RHB Bank. "If the government doesn't step in, the VC/ $\mathrm{PE}$ industry will not have a long-term future. Most of the independent players will conclude the VC business is not economically viable. You are better off having a well-paid job," noted David Fong.

The general consensus was that deal flow was lacking in Malaysia, somewhat better in ASEAN and very good in broader Asia. "You cannot deliver huge homeruns in Malaysia, because the population is too small," said Ken Yew Chan of OSK Ventures. "But there are lots of deals in India and China," noted Chok Kwee Bee, 
Managing Director of Walden International. Two of the top performers in the space, Navis Capital and Kuwait Finance House, did not see deal flow as an issue because their teams make investments in ASEAN as well as broader Asia. Executives, in summary, therefore proposed that a vibrant Malaysian VC/PE industry that invested not only in Malaysia itself but in broader Asia would have sufficient positive externalities to warrant government intervention by the Malaysian government.

\section{Attracting Foreign Capital}

Recent developments certainly indicate that foreign investors deem there to be sufficient deal flow in Malaysia. The 1Malaysia Development fund has succeeded in attracting US\$1.5 billion from PetroSaudi and up to US\$8 billion from China utility giant SGCC to invest in Malaysian private equity deals. These two agreements confirm earlier trends - prior to the recent financial crisis, Southeast Asia had seen a nearly 28 -fold increase in foreign private equity investment levels, from US $\$ 256$ million in 2003 to US\$6.9 billion in 2007. Capital flows from North America and Europe to Southeast Asia suffered a deep shock in 2008, but are likely to once again accelerate when the economic situation in the US and Europe improves. Even in the current economic climate, however, investors in Asia and the Middle East are demonstrating a strong appetite for investing in Southeast Asia, which the following write-up from the Asian Private Equity Review summarises nicely:

Capitalizing on investor appetite for Southeast Asian deals and Malaysia's status as a hub for Islamic finance, CIMB Standard Strategic Advisors announced [in August 2009] that it will be managing a US\$250 million Islamic Infrastructure fund sponsored by the Asian Development Bank and the Islamic Development Bank. The Islamic Infrastructure Fund will seek opportunities in Asia's emerging markets and is one of the first infrastructure funds that is sharīah-compliant. At a time when institutional investors remain cautious in making allocations, the Islamic Infrastructure Fund speaks to the infrastructure investment expertise in Malaysia and its close ties with Islamic investors. ${ }^{42}$

Interviewees agreed that Middle Eastern investors were interested in investing in Southeast Asia. "Middle Eastern investors are very interested in Southeast Asia, and more so if you structure deals to their liking," noted Darawati Hussain, Head of CIMB Private Equity, one of Malaysia's leading PE groups. "Investors in the Middle East are increasingly interested in investing in Southeast Asia. After last year's crisis they're more focused here. We have something to offer them [...] if they haven't looked yet, they will start to look," agreed Joseph Lee of Kuwait Finance House.

Interviewees, however, differed over the significance of Islamic finance as a material factor for investors. It is unclear to what extent foreign investor interest in Malaysia is driven by Islamic finance relative to conventional determinants of investment 
decisions. After all, according to Darawati Hussain, "the long-term growth prospects of ASEAN markets are better than the global average, in spite of political concerns about certain regimes". ${ }^{43}$ Most interviewees argued that shar $\bar{\imath}$ 'ah-compliance was low on the list of priorities for Middle Eastern investors. "It is not really a material factor. Perhaps it is one of the top ten factors, but not the top three. At the end of the day, investors are looking for good deals. How they structure them is merely an option," said David Vicary, Global Director of Islamic Finance at Deloitte. "Middle Eastern investors are sophisticated and are less driven by $\operatorname{shrī'~}^{\prime} a h$-compliance than many assume," noted Ali Zaidi, Head of Islamic Market at Maybank Investment Bank. "People confuse the issue - many investors do prefer shari 'ah-compliant investments, but the principal issues relate to the return, time horizon, and currency," noted Badlisiyah Abdul Ghani, CEO of CIMB Islamic. One executive even stated that "we have a sharī'ah-compliant fund, but to be honest the only difference from our other funds is we have to spend some time structuring our acquisition differently; in the end the results are the same but we just use different names".

Others, like Lim Yong Lee of AMInvestment Bank, emphasised that using Islamic $\mathrm{PE}$ "is a differentiating point. If you have two funds that are the same except one is sharī'ah-compliant, [Middle Eastern] investors will go to the sharī ah-compliant one." Even those who argue that sharī $a h$-compliance is not a significant factor in investor decisions would say that such compliance cannot hurt: "Naturally when you have Middle Eastern people who have capital, it's attractive to talk about this," said Adi Arman of CMS Opus Private Equity. This is particularly true when recent estimates indicate about US\$1.5 trillion of Middle Eastern funds were invested via Islamic financial institutions globally in 2007. Whatever the case, Islamic capital is coming to Malaysia. And the potential for greater investment levels is high: "Middle Eastern investment in Malaysia can be several orders higher than current levels. The main issue relates to information: GCC investors are keen to deploy capital, but they don't know the industries here and location well enough. In the past, they have tried to open branches or subsidiaries to solve this problem," noted David Vicary, Global Director of Islamic Finance at Deloitte.

\section{Other Important Areas: Creating a Nurturing Environment for Entrepreneurs and Venture Capitalists}

Interviewees noted the substantial advancement that had been made in creating a nurturing environment for entrepreneurs. Policymakers should sustain their trajectory in improving this environment, as described below.

Legal. A domain of prime importance in nurturing entrepreneurship is the presence of a sound regulatory and legal framework; interviewees suggested this was not an 
issue in Malaysia. "Capital controls and legal issues are no longer a problem," noted Lim Yong Lee of AMInvestment Bank. "Malaysia has a good corporate governance structure. There are very minor problems for investing in Malaysia," agreed Rafe Haneef, Managing Director at Fajr Capital.

Tax incentives. Malaysia has provided a remarkable number of tax incentives to sustain entrepreneurship and VC/PE. "The venture capital industry is basically not taxed," noted Jennifer Chang, Partner at PricewaterhouseCoopers. Note, however, that a majority of VC/PE groups in Malaysia have not benefited from this incentive as profits are necessary for taxes.

Access to technology. Malaysia, like many nations around the globe over the last two decades, has created a programme to commercialise university technology. These programmes address a real need, but an analysis of their performance around the globe reveals a tendency to select poor investment opportunities. ${ }^{44}$ In addition, the programmes have oftentimes hurt the local venture capital industry through subsidised competition, "discouraging involvement of individuals who had ability to add tremendous value". ${ }^{45}$

Education. As previously mentioned, the Ministry of Entrepreneur Development (KPUn) has made significant strides in educating the public about entrepreneurship. The total number of programme participants in 2001-06 according to one source was $164,786 .{ }^{46}$ If an evaluation deems the program to be efficacious, additional efforts can be made. Following in the footsteps of the prominent MIT $\$ 100 \mathrm{~K}$ business plan competition, most top US universities now host similar competitions. Such efforts can be replicated at major Malaysian universities with little funding. Administrators should focus on ensuring that winners receive social capital - recognition from their peers and society - as a result of winning. Singapore, in a similar effort, has created an annual prize for entrepreneurs who have failed in order to eliminate some of the disincentives involved in trying to start a business.

\section{Policy Recommendations}

High-level appointment to focus on channelling Middle East investment to Malaysia. Malaysia's investment ratio relative to the size of the economy is the second-lowest in Asia after the Philippines. ${ }^{47}$ As noted earlier in this article, Middle Eastern investors have a strong appetite for investing in Southeast Asia. The US $\$ 1.5$ billion investment by PetroSaudi International in 1Malaysia Development confirms investor interest in Malaysia. Much more can be done to build on this success.

It would be worthwhile to consider appointing a prominent senior government minister to build and maintain relationships with large institutional investors in the 
Middle East, to bring investment back to Malaysia. David Vicary, Global Director of Islamic Finance at Deloitte, noted that the leadership in Singapore seems to spend much more time in the Middle East pitching for investment than Malaysian politicians. "The Singapore Prime Minister does it, why can't we get Mahathir to do it as well?" The issue that these executives seized upon was that of a lack of information. "Malaysia has a lot of attractive features - there are competent, Englishspeaking professionals here. The big issue is that we are small and investors are not familiar with us," observed Huzaime Hamid, Investment Committee member at CIMB. In addition, luring capital from abroad for specific projects will do little to build the VC/PE industry in Malaysia; attracting investment in VC/PE funds, on the other hand, will bolster the $\mathrm{VC} / \mathrm{PE}$ industry in addition to the industries in which the VC/PE firm will invest. "There is a constant flow of people to the Gulf from Malaysia to promote standard projects for direct funding, but this is not for funds. Singapore does this the right way - they don't have specific projects in Singapore, so they go to promote their funds," noted Chok Kwee Bee of Walden International.

Creation of a RM1 billion fund-of-funds, where government matches funds from private sector. The second policy proposal is for the Malaysian government to set up a RM1 billion fund-of-funds (FoF), wherein it would match funds invested from the private sector. Due to the strong appetite for deals in the region, policymakers may consider providing 1RM for every 2RM raised from private investors. Fund-of-funds raise capital which is then invested in other funds; those funds then make investments in companies. Such an arrangement is desirable in Malaysia for the following reasons.

Attracting capital. "The FoF structure will be attractive for investors because of its size, which will allow large institutional investors to place capital at levels worthwhile to them," noted Darawati Hussain, Head of CIMB Private Equity.

Distributing capital in a way that bolsters the VC/PE industry. Channelling investments through domestic VC/PE players will ensure the survival of the VC/ PE industry.

Performance. Funds-of-funds reduce investment risk and produce averagely good performance when compared to the rest of the private equity industry. ${ }^{48}$

The fund would have the following features:

- Management. The fund-of-funds would be managed by (1) a fund-of-funds manager who has experience managing FoFs abroad, and (2) local government- 
backed VC/PE groups like MAVCAP, which would monitor the government's investment. The role of the international FoF manager would be to identify and assess applications from local $\mathrm{VC} / \mathrm{PE}$ investors, which Malaysian institutional investors currently say they're not qualified to do. Malaysian investors could also then learn from the FoF manager. Great care should be made in selecting and designing incentives for the manager, however, as numerous US state initiatives have produced low returns as a result of hiring international FoF managers who charged excessive fees or who had a different set of priorities from those intended by policymakers.

On the other hand, excessive government control over investment decisions, whether in funding groups or deals, can be disastrous; investment mandates and caps similar to those levied on MAVCAP, which is forced to invest seed money in some start-ups, will ensure that the fund will not perform. Investors know this, and thus the government cannot be seen as interfering in the fund's investment decisions if the fund is to attract foreign capital and be profitable. "Don't put us in jail if things go wrong. Risk-averse board members can't hold vetoes [...] if we are careful, we can have a true fund like KKR is managing," said Danny Rashdan Yusof, CEO of Maybank Investment Bank.

- Geographical scope and capital controls. The FoF would allow, subject to the approval of the FoF manager, Malaysian VC/PE organisations to team up with other VC/PE organisations in ASEAN and broader Asia. Restricting deals to Malaysia would be problematic because of the aforementioned deal flow issue. "Opening up the fund is crucial. Malaysia is a small country... otherwise it's like setting up a PE fund and saying you can only invest in Nebraska," said Danny Rashdan Yusof of Maybank. Research confirms that a bias for investing locally leads to lower returns in $\mathrm{VC} / \mathrm{PE}$ - a study of 7,600 venture capital investments found that investments made in geographical proximity to the venture capital firm yielded seven percentage points lower returns annually. Presumably, investors had felt an obligation to nurture regional economic activity which clouded their judgment in selecting promising deals. ${ }^{49}$

Partnering with VC/PE organisations outside Malaysia would also allow local organisations to absorb best practices from market leaders abroad, the principal goal of Israel's highly successful government venture capital initiative, and participate in lucrative deals. Allowing such partnerships would also ensure that foreign investee companies would have access to mentors (i.e. the partner $\mathrm{VC} / \mathrm{PE}$ firm) and that monitoring could take place to minimise the risk of bad management. Government officials may resist the prospect of providing public capital that exits the country, but if the goal of a government initiative is to create a sustainable $\mathrm{VC} / \mathrm{PE}$ industry then they must design a fund that allows investors to generate good returns. A compromise might result 
in a restriction that a certain percentage of the funds remain in the country, or that investee headquarters be moved to Malaysia.

- Sharī'ah-compliant RM300 million tranche. It would be advantageous to make a portion of the fund sharī' $a$ h-compliant. Aside from promoting Islamic Finance, a core goal of the Malaysian government, the shari 'ah-compliance "would be a differentiating factor for investors from other funds," said Rashid Hussain, founder of RHB Bank. There is disagreement about whether sharī 'ah-compliance would restrict deal flow, but those organisations which have raised funds from Middle Eastern investors note that such investors' vision of sharī'ah-compliance tends to be stricter than in Malaysia. "Being GCC-sharī'ah-compliant certainly does restrict deal flow for us. All other issues like appropriate gearing ratios can be solved, since you have three years to convert to Islamic debt," noted Joseph Lee of Kuwait Finance House. "It may do so minimally, but this should not be a significant problem. You can set up SPVs that are fully sharī $a h$-complaint, and can set up structures and waqfs to transfer return," said Ali Zaidi, Head of Islamic Market at Maybank Investment Bank.

- Incentives for investors. Despite the numerous advantages to investors associated with the FoF proposal, additional incentives may be optimal. Some interviewees suggested that the government consider a partial or full government guarantee to domestic institutional investors. Such a policy, however, would distort investment selection by shifting all the risk away from the private $\mathrm{VC} / \mathrm{PE}$ and likely result in greater adverse selection and low returns. Other interviewees argued that the government should step in to "persuade" domestic institutional investors to make allocations to $\mathrm{VC} /$ PE. "For the Employers' Provident Fund, a 0.25 per cent or 0.5 per cent would mean little, but would be a significant boon for the Malaysian VC/PE industry, and, therefore, economy," said one executive. Indeed, pension funds globally on average allocate " 4.8 per cent of their assets under management to private equity, and the twenty largest pension funds allocate 8.6 per cent of their combined AuM" ${ }^{50}$ But market opportunities in VC/PE globally may be different from those in Malaysia. Forcing domestic institutional investors to make certain allocations despite their perception of the market opportunity is not a good idea, especially when capital from foreign investors comfortable with the asset class is available.

One type of incentive that has proven successful in Australian and Israeli government initiatives is the inclusion of a buyout clause. Private investors using such a clause would have the option to buy out the government's share of an investment including accrued interest within five years. This policy would channel an additional portion of the 'upside' to institutional investors 
at the expense of the government, and may or may not be needed depending on institutional investor interest in the Islamic FoF.

- Transparency and evaluation. To avoid some of the problems that have plagued past Malaysian government initiatives, the evaluation criteria for applicant funds should be openly published. In addition, while avoiding overly burdensome reporting requirements that would dissuade good teams from participating, a programme to evaluate the effects of the government initiative using techniques such as regression discontinuity analysis should be instituted. In assessing the performance of the FoF initiative, policymakers need to be able to understand years hence how the Malaysian VC/PE industry would have performed had the initiative not been enacted.

\section{Notes}

1. John Drabble, "The Economic History of Malaysia", EH.Net Encyclopedia, 31 July 2004, available online at http://eh.net/encyclopedia/article/drabble.malaysia (accessed on 24 March 2010).

2. YBhg Dato Dr Nik Ramlah Nik Mahmood, "Keynote Address", Islamic Venture Capital and Private Equity Conference 2008.

3. Tim Jenkinson, "The Development and Performance of European Private Equity", available online at http://economics.ouls.ox.ac.uk/14303/1/EurPrivateEquity.pdf (accessed on 24 March 2010), 19.

4. Ibid.

5. Josh Lerner, Antionette Schoar and Wan Wong, "Smart Institutions, Foolish Choices: The Limited Partner Performance Puzzle", NBER Working Paper Series 11136 [Cambridge MA, February 2005] available online at http://www.nber.org/papers/w11136.pdf (accessed on 24 March 2010).

6. Coller Capital, "Global Private Equity Barometer, Summer 2009”, available online at http://www. collercapital.com/assets/images/press/Barometer_Summer_09.pdf (accessed on 24 March 2010), 5.

7. Ludovic Phalippou and Oliver Gottschalg, "Performance of Private Equity Funds", Review of Financial Studies 22, no. 4 (2009), 1747-76.

8. Ibid.

9. Paul Kedrosky, Right-Sizing the U.S. Venture Capital Industry (Ewing Marion Kauffman Foundation, 2009), available online at http://papers.ssrn.com/sol3/papers.cfm?abstract_id=1456431 (accessed on 24 March 2010), 5.

10. Ibid., 5 .

11. Josh Lerner, Boulevard of Broken Dreams (Princeton: Princeton University Press, 2009), 43.

12. BVCA [British Venture Capital Association], "The Economic Impact of Private Equity in the UK 2007”, February 2008, available online at http:/www.bvca.co.uk/assets/features/show/ TheEconomicImpactofPrivateEquityintheUK2007 (accessed on 24 March 2010), 9.

13. Lerner, Boulevard, 62.

14. World Economic Forum, "The Global Economic Impact of Private Equity Report 2010, Working Papers Vol. 3", available online at www.weforum.org/en/media/publications/PrivateEquityReports/ index.htm (accessed on 24 March 2010), vii.

15. N. Bloom, R. Sadun and J. Van Reenen, "Do Private Equity-Owned Firms Have Better Management Practices?" in: A. Gurung and J. Lerner (eds), Globalization of AlternativeInvestments Working Papers. Volume 2: Global Economic Impact of Private Equity 2009 (New York: World Economic Forum USA, 2009), 1-23.

16. Ibid., 1-23.

17. World Economic Forum, "The Global Economic Impact", viii. 
18. Lerner, Boulevard, 5.

19. Ibid., 10 .

20. Ibid., 68 .

21. World Economic Forum, "The Global Economic Impact", viii.

22. "Malaysia Hopes to Become Islamic Venture Capital Hub", The Edge [Kuala Lumpur], 21 May 2009.

23. David Brooks, "The Tel Aviv Cluster", New York Times, 12 January 2010.

24. Douglass North, Growth and Structural Change (New York: Norton, 1981).

25. Alesina, Alberto, Public Goods and Ethnic Divisions (Cambridge, MA: Harvard University Press, 1997).

26. Syahira Hamidon, The Development of Malay Entrepreneurship in Malaysia (Auckland, New Zealand: Massey University, 2009).

27. Ralph Arthur Simpson, "Government Intervention in the Malaysian Economy, 1970-1990: Lessons for South Africa", master's thesis, University of the Western Cape, available online at http://etd. uwc.ac.za/usrfiles/modules/etd/docs/etd_init_6005_1177061493.pdf (accessed on 24 March 2010), 71.

28. Lerner, Boulevard, 113.

29. "Malaysian Productivity Corporation Building Entrepreneurship in Malaysia", available online at http://www.mpc.gov.my/files/BUILDING\%20ENTREPRENEURSHIP.pdf (accessed on 24 March 2010).

30. Lerner, Boulevard, 113.

31. Norfaizah Othman et al., "Entrepreneurial Acculturation in Malaysia: Efforts and Achievements", available online at http://mpra.ub.uni-muenchen.de/8980/1/paper_ice3.pdf [Munich, 2008] (accessed on 24 March 2010).

32. Lerner, Boulevard, 114.

33. Ibid., 130.

34. Asian Development Bank, Key Indicators 2001: Growth and Change in Asia and the Pacific (New York: Oxford University Press, 2001), also available online at http://www.adb.org/Documents/ Books/Key_Indicators/2001/rt11_ki2001.xls (accessed on 24 March 2010).

35. MTDC was established in 1992 but a venture arm was added later.

36. "Fish Out of Water", The Economist, 29 October 2009.

37. "Saudi Funds in 1Malaysia a Boon to all Malaysians, Says Najib", The Star [Kuala Lumpur], 1 October 2009.

38. Tim Friedman (ed.), 2010 Preqin Global Private Equity Report (London: Preqin, 2010), 76.

39. Ibid., 21.

40. Malaysian Venture Capital Development Council, "Statistic: Venture Capital, Year 2007", available online at http://www.mvcdc.com.my/details.asp?txtCatID=16 (accessed on 24 March 2010).

41. Lerner, Boulevard, 101.

42. Asia Private Equity Review (August 2009), available online at http://www.asiape.com/aper/aper_ issues/aper0908.html (accessed on 24 March 2010).

43. Darawati Hussain, "Private Equity: An Asian Perspective", in: Sohail Jaffer (ed.), Islamic Asset Management: Forming the Future for Shari'a-Compliant Investment Strategies (London: Euromoney Books, 2004), 103.

44. Lerner, Boulevard, 96-7.

45. Ibid., 96-7.

46. Othman, "Entrepreneurial Acculturation".

47. "Malaysia Gets $\$ 1.5$ Billion Saudi-Investment", Reuters, 30 September 2009, available online at http://www.forexpros.com/news/interest-rates-news/update-1-malaysia-gets-\$1.5-bln-saudiinvestment-91031 (accessed on 24 March 2010).

48. Friedman (ed.), 2010 Preqin Global Private Equity Report, 67.

49. Lerner, Schoar and Wong, "Smart Institutions".

50. Friedman (ed.), 2010 Preqin Global Private Equity Report, 76. 